\title{
The herpetofauna of Parque Nacional Pico Bonito, Honduras
}

\author{
James R. McCranie ${ }^{1}$ and Franklin E. Castañeda ${ }^{2}$ \\ 110770 SW 164th Street, Miami, Florida 33157, USA. E-mail: jmccrani@bellsouth.net. \\ 2 Universidad de Costa Rica, San José, Costa Rica. E-mail: fecastaneda@yahoo.com.
}

\begin{abstract}
The herpetofauna of Parque Nacional Pico Bonito, Honduras. Seventy-three species of amphibians and reptiles (six salamanders, 20 anurans, 20 lizards, and 27 snakes) are known from Parque Nacional Pico Bonito, Honduras. The physiography, climate, vegetation, and microhabitats of the park are briefly described. Forty-four species are recorded from Lowland Moist Forest, 45 from Premontane Wet Forest, and 14 from Lower Montane Wet Forest. The primary microhabitat and relative abundance of each species are indicated and population declines are discussed.
\end{abstract}

Keywords: Amphibians, amphibian decline, reptiles, Parque Nacional Pico Bonito, Honduras.

\section{Introduction}

A recent series of publications (Wilson and McCranie 1998, 2003, 2004a, c, Wilson et al. 2001, McCranie and Wilson 2002, McCranie 2005) have addressed the issues of the conservation status of the Honduran herpetofauna, the declining populations of some of these amphibians and reptiles, and the efficacy of the existing system of biotic reserves in Honduras in protecting these animals. The status of the amphibian populations in Parque Nacional Pico Bonito, in fact, was the subject of the first of these papers (Wilson and McCranie, 1998).

It is becoming increasingly evident that biodiversity decline, as discussed in more

Received 3 November 2004.

Accepted 21 June 2005.

Distributed October 2005. general terms (Wilson 1988, 1992, Wilson and Perlman 2000) and elsewhere for amphibians and reptiles (Young et al. 1999), is also occurring in Honduras despite the existence of a robust system of biotic reserves in the country. Wilson et al. (2001) and Wilson and McCranie (2004a) have explored some of the reasons for these population declines.

Espinal et al. (2001) reported on the composition, distribution, and conservation status of the herpetofauna of Parque Nacional La Muralla in the northwestern portion of the Honduran department of Olancho. This paper deals with the composition, distribution, and conservation status of the herpetofauna of Parque Nacional Pico Bonito, a large park located in the central portion of the Cordillera Nombre de Dios, the long mountain range paralleling the central portion of the northern coast of Honduras.

Since 1980, we have made numerous trips and worked extensively in the Quebrada de Oro 
area on the southern face of the cordillera. We have made collections on the park side of the Río Cangrejal along the northeastern border of the park, as well as from the vicinity of a forestry school station situated at the base of the northern face of the cordillera.

\section{Material and Methods}

Fieldwork for this study is summarized as follows: McCranie made eight trips totaling 54 days (1-4 June 1980, 14-17 August 1982, 16-19 August 1984, 17-24 May 1988, 24 June 1989, 1-7 August 1989, 11-21 February 1995, and 25 May-9 June 1996). Both authors made one 20-trip from 29 January-17 February 2003. In addition, we have examined amphibians collected in the park by G. A. Cruz and G. Köhler and Köhler also provided us with a list of the reptiles he collected in the park.

The Coefficient of Biogeographic Resemblance algorithm (Duellman 1990) was used to demonstrate herpetofaunal relationships among the three forest formations in the park. The formula is CBR $=2 \mathrm{C} /\left(\mathrm{N}_{1}+\mathrm{N}_{2}\right)$, where $\mathrm{C}$ is the number of species in common to both formations, $N_{1}$ is the number of species in the first formation, and $\mathrm{N}_{2}$ is the number of species in the second formation.

Locality data for each species are included in Appendix I (museum numbers for amphibians included in McCranie and Wilson, 2002 are not listed herein).

\section{Study Site}

Parque Nacional Pico Bonito is located in the central portion of the Honduran department of Atlántida (Figure 1, Appendix II) and the northcentral portion of the department of Yoro, south and west of the city of La Ceiba. The park covers an area of approximately $565 \mathrm{~km}^{2}$ (56,774 ha), with a nuclear zone of about $57 \mathrm{~km}^{2}$ (5737 ha) (Sánchez et al. 2002), although a much larger nuclear zone has recently been proposed (Anonymous 2001). A forestry school station, which also allows visitors easy access to explore the park, is situated at 120 m elevation near the city of La Ceiba. Elevations in the park range from about 10 to $2480 \mathrm{~m}$, with the current nuclear zone extending from $1800 \mathrm{~m}$ upwards.

Parque Nacional Pico Bonito is located in the northern part (Northern Cordillera) of the largest physiographic area in Honduras, the Serranía (Wilson et al. 2001). The park consists of the central part of the Cordillera Nombre de Dios and a portion of the coastal plain (Nombre de Dios Piedmont) on its windward side (see McCranie and Wilson 2002 for a discussion of the physiography of these two regions).

One reason a significant amount of forest remains to merit establishment of a biotic reserve in the central region of the Cordillera Nombre de Dios is because the windward and leeward faces of this range are extremely steep and relatively difficult to ascend. Nonetheless, significant deforestation has occurred in much of the buffer zone of this park, as well as much of the nuclear zone lying along the Quebrada de Oro southward to the northern slopes of Montaña de Corozal.

Four climatic zones occur in Parque Nacional Pico Bonito viz., Lowland Wet, Intermediate Wet, Intermediate Dry, and Highland Wet. The following is summarized from Wilson and Meyer (1985). The Lowland Wet climate in Honduras is restricted to the Caribbean coast and occurs from sea level to about 600 m elevation. Rainfall is at least $2000 \mathrm{~mm}$ per year with the rainy season occurring from May to December, and the mean annual temperature for this climatic zone is greater than $24^{\circ} \mathrm{C}$. The Intermediate Wet climate occurs at elevations between $600-1500 \mathrm{~m}$ along the Caribbean versant and on some interior mountain ranges and is characterized by annual precipitation greater than $2000 \mathrm{~mm}$ and mean annual temperature between $18-24^{\circ} \mathrm{C}$. The Intermediate Dry climate is found only along the leeward slopes along the southern edge of the park, between about 600-1500 m elevation, and is characterized by annual precipitation of less than $2000 \mathrm{~mm}$ and mean annual temperature between $18-24^{\circ} \mathrm{C}$. The Highland Wet climate occurs primarily above $1500 \mathrm{~m}$ elevation and is 


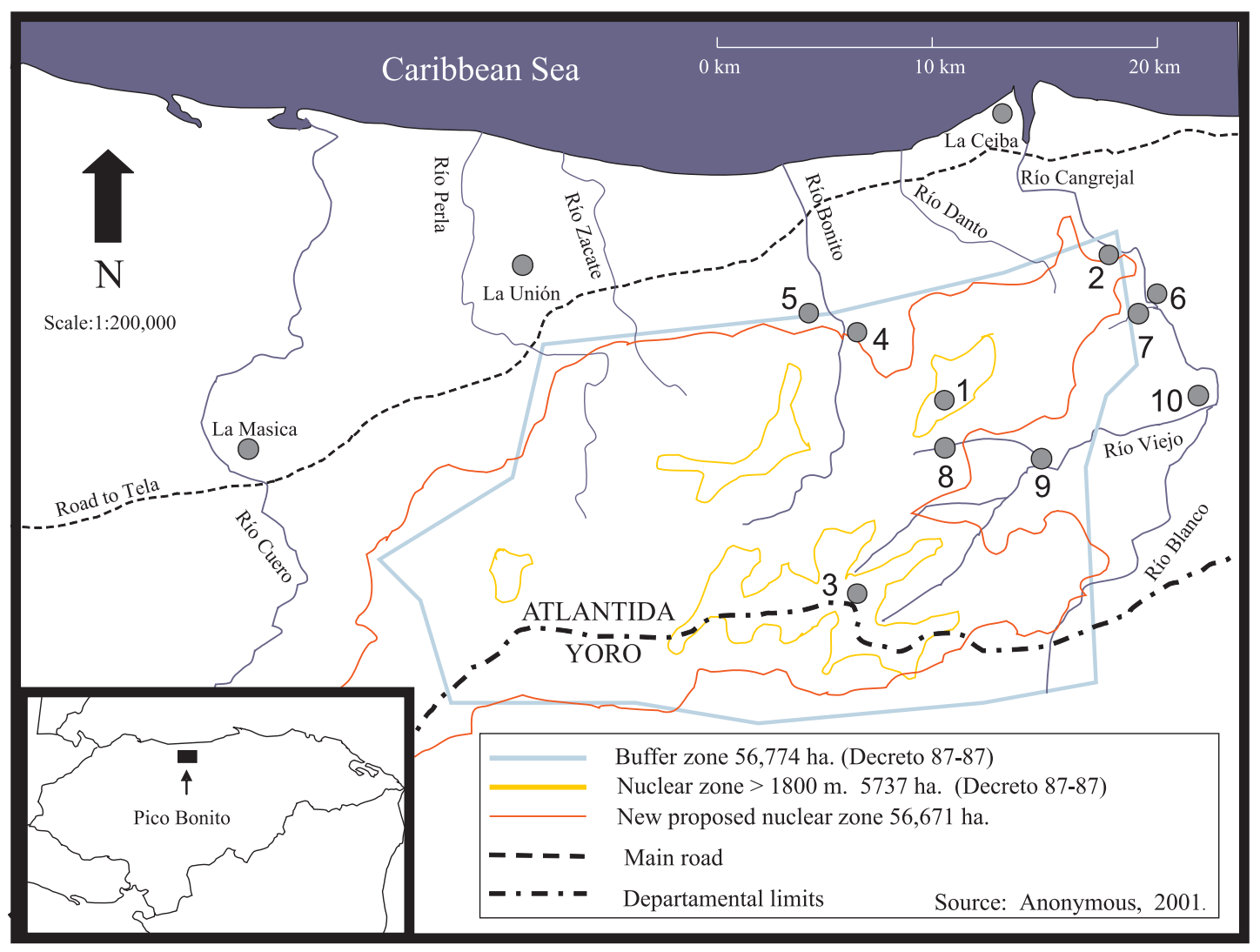

Figure 1 - Map of Parque Nacional Pico Bonito area showing pertinent localities. Numbered localities are: (1) Cerro Búfalo; (2) 7.4 km SSE of La Ceiba; (3) Montaña de Corazón; (4) CURLA Forestry Station; (5) Liberia; (6) Las Mangas; (7) Quebrada La Muralla; (8) Quebrada de Oro; (9) Los Planes; and (10) Río Viejo Village.

characterized by $1500 \mathrm{~mm}$ or more of annual precipitation and a mean annual temperature of less than $18^{\circ} \mathrm{C}$.

Vegetation in Parque Nacional Pico Bonito can be allocated to four Holdridge (1967) forest formations. The Lowland Moist Forest extends from sea level to about $600 \mathrm{~m}$ on the windward face of Cordillera Nombre de Dios and is characterized by a mean annual precipitation range of 2000-4000 $\mathrm{mm}$ and a mean annual temperature of more than $24^{\circ} \mathrm{C}$. Premontane Wet Forest occupies elevations between about 600$1500 \mathrm{~m}$ and is characterized by a mean annual precipitation range of $2000-4000 \mathrm{~mm}$ and a mean annual temperature range of $18-24^{\circ} \mathrm{C}$. Premontane Moist Forest is limited to a small area on the leeward slopes along the southern boundary of the park from about 600-1500 m with a mean annual precipitation range of $1000-2000 \mathrm{~mm}$ and a mean annual temperature range of $18-24^{\circ} \mathrm{C}$. No amphibians and reptiles have been collected in this formation in the park. Lower Montane Wet Forest occurs at elevations above about $1500 \mathrm{~m}$ with a mean annual precipitation range of 2000$4000 \mathrm{~mm}$ and a mean annual temperature range of $12-18^{\circ} \mathrm{C}$.

Agudelo (1987) noted that some of the common species of trees of the Lowland Moist 
Forest of the Honduran Caribbean coast belong to the genera Astronium, Cedrela, Pithecolobium, Terminalia, and Vochysia. In the primary forest around the CURLA Forestry Station, more than 120 species of plants have been reported. Some of the most common trees at this site are species of the genera Sterculia, Dialium, Pithecolobium, Terminalia, Jacaranda, Miconia, Rheedia, Mouriri, Meliosma, Ouratea, Rinorea, Rollinia, Podocarpus, Mollinedia, Cordia, and Symphonia (Mejia 1993). One hundred and forty-six species of trees have been reported and described for the Honduran Caribbean coast, and more than 400 species are expected to be present in the park (Thirakul 1998).

Numerous microhabitats for amphibians and reptiles exist within the park. Included are streams and rivers of varying sizes, a few small temporary and permanent ponds in disturbed areas below $600 \mathrm{~m}$, and forest types ranging from tropical lowland rainforest to wind scrub at the highest elevations of the cordillera. Parts of the park contain denuded areas and secondary and primary forests.

Specimens collected in the immediate environs of lotic (streams and rivers) or lentic (ponds) situations were recorded as being streamside or pondside inhabitants, respectively, whereas those collected in the forest away from surface water were recorded as forest inhabitants. Height above the ground also was noted for the specimens collected. Those found on the ground, streamside boulders, underneath logs, moss mats, or other surface debris, or inside logs were scored as being terrestrial. Specimens found active on vegetation from a few $\mathrm{cm}$ above the ground upward were scored as being arboreal.

\section{Results}

\section{Composition and Taxonomic Comments}

Seventy-three species have been identified in Parque Nacional Pico Bonito (Table 1), six salamanders (8.2\%), 20 anurans (27.4\%), 20 lizards (27.4\%), and 27 snakes (37.0\%). Of these, two are taxonomically problematic. The single specimen of Eleutherodactylus laticeps from the park (KU 209039) was tentatively included in E. laticeps by McCranie and Wilson (2002). Specimens resembling Norops rodriguezii from the park are tentatively assigned to that species. Genetic data and males with fully everted hemipenes are needed before the identity of this population can be confirmed.

\section{Biogeographical Resemblance}

The Coefficient of Biogeographic Resemblances (CBR) for the three forest formations in the park that have been adequately sampled are shown in Table 2. The highest CBR value (0.47) is that between Lowland Moist Forest and Premontane Wet Forest, and the lowest (0.07) between Lowland Moist Forest and Lower Montane Wet Forest. As expected, the highest average CBR value (0.37) is that for the Premontane Wet Forest formation, given its intermediate altitudinal position.

\section{Broad Patterns of Geographical Distribution}

As did Wilson and Meyer (1985), Wilson et al. (2001), and McCranie and Wilson (2002), we placed the species occurring in this park into a set of distributional categories based on the entire extent of their geographic range (Table 1). Three of the categories used by Wilson et al. (2001) do not apply to this paper (species with the northern terminus of the range in the United States and the southern terminus in Nuclear Middle America [category C], marine species [category K], and insular and/or coastal species [category L]). The applicable categories are as follows:

A. Northern terminus of the range in the United States (or Canada) and southern terminus in South America;

B. Northern terminus of the range in the United 
Table 1 - Distribution of the 73 species of amphibians and reptiles known from Parque Nacional Pico Bonito. Abbreviations - Forest Formations: LMF, Lowland Moist Forest; PWF, Premontane Wet Forest; LMWF, Lower Montane Wet Forest; Primary Microhabitat: A, arboreal; T, terrestrial; F, forest inhabitant; P, pondside inhabitant; S, streamside inhabitant; Relative Abundance: C, common; I, infrequent; R, rare; Conservation Status: S, stable populations in Parque Nacional Pico Bonito; D, Parque Nacional Pico Bonito populations declining; E, extinct or extirpated from park; N, no data on population status. See text for explanation of Broad Distribution Pattern abbreviations.

\begin{tabular}{|c|c|c|c|c|c|c|}
\hline Species & $\begin{array}{l}\text { Elevational } \\
\text { Range (m) }\end{array}$ & $\begin{array}{c}\text { Forest } \\
\text { Formations }\end{array}$ & $\begin{array}{c}\text { Broad } \\
\text { Distribution } \\
\text { Pattern }\end{array}$ & $\begin{array}{c}\text { Primary } \\
\text { Microhabitat }\end{array}$ & $\begin{array}{c}\text { Relative } \\
\text { Abundance }\end{array}$ & $\begin{array}{c}\text { Conser- } \\
\text { vation } \\
\text { Status }\end{array}$ \\
\hline Bolitoglossa mexicana & $160-600$ & LMF & $\mathrm{F}$ & A, F, S & $\mathrm{R}$ & $\mathrm{N}$ \\
\hline Bolitoglossa porrasorum & $980-1680$ & PWF, LMWF & $\mathrm{J}$ & A, F, S & $\mathrm{C}$ & S \\
\hline Bolitoglossa rufescens & 120-990 & LMF, PWF & I & $\mathrm{A}, \mathrm{F}$ & $\mathrm{C}$ & S \\
\hline Nototriton barbouri & $980-1540$ & PWF, LMWF & $\mathrm{J}$ & $\mathrm{A}, \mathrm{F}$ & $\mathrm{R}$ & $\mathrm{S}$ \\
\hline Oedipina cyclocauda & $120-500$ & LMF & $\mathrm{H}$ & $\mathrm{T}, \mathrm{F}$ & I & S \\
\hline Oedipina gephyra & 1580 & LMWF & $\mathrm{J}$ & $\mathrm{T}, \mathrm{F}$ & $\mathrm{R}$ & $\mathrm{N}$ \\
\hline Atelophryniscus chrysophorus & $750-1760$ & PWF, LMWF & $\mathrm{J}$ & T, F, S & $\mathrm{C}$ & $\mathrm{E}$ \\
\hline Bufo leucomyos & $120-1000$ & LMF, PWF & $\mathrm{J}$ & T, F, S & $\mathrm{C}$ & $S$ \\
\hline Bufo marinus & $120-600$ & LMF & A & T, F, P & $\mathrm{C}$ & $S$ \\
\hline Bufo valliceps & $80-600$ & LMF & $\mathrm{E}$ & T, F, P & $\mathrm{I}$ & $S$ \\
\hline Hyalinobatrachium fleischmanni & 1000 & PWF & $\mathrm{D}$ & $\mathrm{A}, \mathrm{S}$ & $\mathrm{R}$ & $\mathrm{N}$ \\
\hline Duellmanohyla salvavida & $90-1000$ & LMF, PWF & $\mathrm{J}$ & $\mathrm{A}, \mathrm{S}$ & $\mathrm{C}$ & $\mathrm{D}$ \\
\hline Plectrohyla chrysopleura & $930-1550$ & PWF, LMWF & $\mathrm{J}$ & A, T, S & $\mathrm{C}$ & $\mathrm{D}$ \\
\hline Ptychohyla spinipollex & $500-1580$ & LMF, PWF, LMWF & $\mathrm{J}$ & A, T, S & $\mathrm{C}$ & $S$ \\
\hline Smilisca baudinii & $80-600$ & LMF & B & $\mathrm{A}, \mathrm{P}$ & I & $S$ \\
\hline Eleutherodactylus aurilegulus & $100-1110$ & LMF, PWF & $\mathrm{J}$ & $\mathrm{T}, \mathrm{S}$ & $\mathrm{C}$ & $\mathrm{S}$ \\
\hline Eleutherodactylus chac & $730-1000$ & PWF & I & $\mathrm{T}, \mathrm{F}$ & I & $\mathrm{D}$ \\
\hline Eleutherodactylus chrysozetetes & $800-1000$ & PWF & $\mathrm{J}$ & $\mathrm{T}, \mathrm{S}$ & $\mathrm{C}$ & $\mathrm{E}$ \\
\hline Eleutherodactylus cruzi & 1520 & LMWF & $\mathrm{J}$ & $\mathrm{T}, \mathrm{S}$ & $\mathrm{R}$ & $\mathrm{E}$ \\
\hline Eleutherodactylus fecundus & $780-1260$ & PWF & $\mathrm{J}$ & $\mathrm{T}, \mathrm{S}$ & $\mathrm{C}$ & $\mathrm{E}$ \\
\hline Eleutherodactylus laticeps & 1270 & PWF & $\mathrm{F}$ & $\mathrm{T}, \mathrm{S}$ & $\mathrm{R}$ & $\mathrm{N}$ \\
\hline Eleutherodactylus noblei & $120-130$ & LMF & $\mathrm{H}$ & $\mathrm{T}, \mathrm{F}$ & $\mathrm{I}$ & $\mathrm{S}$ \\
\hline Eleutherodactylus ridens & $120-960$ & LMF, PWF & G & $\mathrm{A}, \mathrm{F}$ & $\mathrm{C}$ & $\mathrm{S}$ \\
\hline Eleutherodactylus saltuarius & $1550-1680$ & LMWF & $\mathrm{J}$ & $\mathrm{T}, \mathrm{F}$ & $\mathrm{R}$ & $\mathrm{D}$ \\
\hline Leptodactylus melanonotus & 80-290 & LMF & $\mathrm{D}$ & $\mathrm{T}, \mathrm{S}$ & $\mathrm{I}$ & $\mathrm{N}$ \\
\hline Rana maculata & $600-1100$ & LMF, PWF & I & $\mathrm{T}, \mathrm{S}$ & $\mathrm{C}$ & $S$ \\
\hline Sphaerodactylus dunni & са. 100-230 & LMF & $\mathrm{J}$ & $\mathrm{T}, \mathrm{F}$ & $\mathrm{R}$ & $S$ \\
\hline Sphaerodactylus millepunctatus & 120-200 & LMF & $\mathrm{H}$ & $\mathrm{T}, \mathrm{F}$ & $\mathrm{I}$ & $\mathrm{S}$ \\
\hline Thecadactylus rapicauda & 120-200 & LMF & G & $\mathrm{A}, \mathrm{F}$ & $\mathrm{R}$ & $\mathrm{S}$ \\
\hline Basiliscus vittatus & $120-1400$ & LMF, PWF & $\mathrm{D}$ & A, S & C & $\mathrm{S}$ \\
\hline Corytophanes cristatus & $600-800$ & LMF, PWF & $\mathrm{D}$ & $\mathrm{A}, \mathrm{F}$ & I & $S$ \\
\hline Sceloporus malachiticus & 830-1780 & PWF, LMWF & $\mathrm{H}$ & $\mathrm{A}, \mathrm{F}$ & I & $\mathrm{S}$ \\
\hline Norops biporcatus & 120 & LMF & $\mathrm{D}$ & A, F, S & I & $\mathrm{S}$ \\
\hline
\end{tabular}


Table 1. Continued

\begin{tabular}{|c|c|c|c|c|c|c|}
\hline Species & $\begin{array}{l}\text { Elevational } \\
\text { Range (m) }\end{array}$ & $\begin{array}{c}\text { Forest } \\
\text { Formations }\end{array}$ & $\begin{array}{c}\text { Broad } \\
\text { Distribution } \\
\text { Pattern }\end{array}$ & $\begin{array}{c}\text { Primary } \\
\text { Microhabitat }\end{array}$ & $\begin{array}{c}\text { Relative } \\
\text { Abundance }\end{array}$ & $\begin{array}{c}\text { Conser- } \\
\text { vation } \\
\text { Status }\end{array}$ \\
\hline Norops lemurinus & са. $80-880$ & LMF, PWF & E & $\mathrm{A}, \mathrm{F}$ & I & S \\
\hline Norops loveridgei & 830-1580 & PWF, LMWF & $\mathrm{J}$ & $A, F$ & $\mathrm{C}$ & S \\
\hline Norops purpurgularis & $1630-1820$ & LMWF & $\mathrm{J}$ & $\mathrm{A}, \mathrm{F}$ & $\mathrm{C}$ & S \\
\hline Norops rodriguezii & $780-1500$ & PWF, LMWF & $\mathrm{F}$ & A, F, S & $\mathrm{C}$ & $\mathrm{S}$ \\
\hline Norops sericeus & са. 80 & LMF & E & A, S & $\mathrm{R}$ & $\mathrm{N}$ \\
\hline Norops tropidonotus & са. 80-940 & LMF, PWF & $\mathrm{F}$ & $\mathrm{A}, \mathrm{F}$ & $\mathrm{C}$ & S \\
\hline Norops zeus & 90-900 & LMF, PWF & $\mathrm{J}$ & $A, F$ & $\mathrm{C}$ & S \\
\hline Eumeces sumichrasti & $120-880$ & LMF, PWF & $\mathrm{F}$ & T, F, S & I & S \\
\hline Sphenomorphus cherriei & $120-1000$ & LMF, PWF & $\mathrm{E}$ & $\mathrm{T}, \mathrm{F}$ & $\mathrm{C}$ & S \\
\hline Ameiva festiva & $100-1000$ & LMF, PWF & $\mathrm{G}$ & $\mathrm{T}, \mathrm{F}$ & $\mathrm{C}$ & S \\
\hline Ameiva undulata & са. 80-100 & LMF & $\mathrm{E}$ & T, S & I & S \\
\hline Cnemidophorus lemniscatus & $100-400$ & LMF & $\mathrm{G}$ & $\mathrm{T}, \mathrm{S}$ & $\mathrm{C}$ & S \\
\hline Lepidophyma flavimaculatum & $120-940$ & LMF, PWF & $\mathrm{E}$ & $\mathrm{T}, \mathrm{F}$ & $\mathrm{R}$ & S \\
\hline Typhlops stadelmani & 320 & LMF & $\mathrm{J}$ & $\mathrm{T}, \mathrm{F}$ & $\mathrm{R}$ & S \\
\hline Boa constrictor & $780-940$ & PWF & $\mathrm{D}$ & T, F, S & $\mathrm{R}$ & S \\
\hline Ungaliophis continentalis & 990 & PWF & $\mathrm{I}$ & $\mathrm{T}, \mathrm{S}$ & $\mathrm{R}$ & $\mathrm{N}$ \\
\hline Adelphicos quadrivirgatum & 120 & LMF & $\mathrm{F}$ & $\mathrm{T}, \mathrm{F}$ & I & S \\
\hline Chironius grandisquamis & $120-990$ & LMF, PWF & G & A, T, S & I & S \\
\hline Clelia clelia & 120 & LMF & $\mathrm{G}$ & $\mathrm{T}, \mathrm{F}$ & $\mathrm{R}$ & $\mathrm{N}$ \\
\hline Coniophanes fissidens & 800-990 & PWF & $\mathrm{D}$ & $\mathrm{T}, \mathrm{F}$ & I & S \\
\hline Dendrophidion nuchale & 840 & PWF & G & $\mathrm{T}, \mathrm{F}$ & $\mathrm{R}$ & $\mathrm{N}$ \\
\hline Dendrophidion percarinatum & $120-500$ & LMF & G & $\mathrm{T}, \mathrm{F}$ & I & S \\
\hline Dryadophis melanolomus & $120-840$ & LMF, PWF & $\mathrm{E}$ & $\mathrm{T}, \mathrm{F}$ & $\mathrm{R}$ & S \\
\hline Drymobius chloroticus & $780-940$ & PWF & $\mathrm{F}$ & T,S & $\mathrm{R}$ & $\mathrm{D}$ \\
\hline Drymobius margaritiferus & 800 & PWF & A & $\mathrm{T}, \mathrm{F}$ & $\mathrm{R}$ & $\mathrm{N}$ \\
\hline Hydromorphus concolor & 900 & PWF & $\mathrm{H}$ & T, S & $\mathrm{R}$ & $\mathrm{D}$ \\
\hline Imantodes cenchoa & $120-1620$ & LMF, LMWF & $\mathrm{D}$ & $\mathrm{A}, \mathrm{F}$ & I & S \\
\hline Lampropeltis triangulum & 1140 & PWF & A & $\mathrm{T}, \mathrm{F}$ & $\mathrm{R}$ & $\mathrm{N}$ \\
\hline Leptodeira septentrionalis & $840-960$ & PWF & A & $\mathrm{A}, \mathrm{F}$ & I & $\mathrm{S}$ \\
\hline Leptophis ahaetulla & $100-1000$ & LMF, PWF & $\mathrm{D}$ & $\mathrm{A}, \mathrm{T}, \mathrm{S}$ & I & S \\
\hline Leptophis mexicanus & са. $60-940$ & LMF, PWF & $\mathrm{E}$ & $\mathrm{A}, \mathrm{F}$ & $\mathrm{R}$ & S \\
\hline Ninia sebae & 120 & LMF & E & $\mathrm{T}, \mathrm{F}$ & I & $\mathrm{S}$ \\
\hline Oxybelis aeneus & 120 & LMF & A & $\mathrm{A}, \mathrm{F}$ & I & $\mathrm{S}$ \\
\hline Pseustes poecilonotus & 100 & LMF & $\mathrm{D}$ & $\mathrm{A}, \mathrm{F}$ & $\mathrm{R}$ & $\mathrm{N}$ \\
\hline Sibon nebulatus & 1500 & LMWF & $\mathrm{D}$ & $\mathrm{A}, \mathrm{F}$ & $\mathrm{R}$ & $\mathrm{N}$ \\
\hline Xenodon rabdocephalus & 130 & LMF & $\mathrm{D}$ & $\mathrm{T}, \mathrm{F}$ & I & $\mathrm{S}$ \\
\hline Micrurus nigrocinctus & $120-830$ & LMF, PWF & G & $\mathrm{T}, \mathrm{F}$ & $\mathrm{C}$ & $\mathrm{S}$ \\
\hline Bothriechis marchi & 1090 & PWF & $\mathrm{J}$ & A, S & $\mathrm{R}$ & $\mathrm{D}$ \\
\hline Bothriechis schlegelii & 860 & PWF & G & A,S & $\mathrm{R}$ & $\mathrm{N}$ \\
\hline Bothrops asper & $880-1160$ & PWF & $\mathrm{D}$ & $\mathrm{T}, \mathrm{F}$ & $\mathrm{C}$ & $\mathrm{S}$ \\
\hline
\end{tabular}


Table 2 - CBR matrix of herpetofaunal relationships for the three forest formations in Parque Nacional Pico Bonito. Abbreviations - LMF, Lowland Moist Forest; PWF, Premontane Wet Forest; LMWF, Lower Montane Wet Forest; N, number of species in each formation; N, number of species in common between the two formations; N, Coefficient of Biogeographic Resemblance.

\begin{tabular}{lccc}
\hline & LMF & PWF & LMWF \\
\hline LMF & $\mathbf{4 4}$ & 21 & 2 \\
PWF & 0.47 & $\mathbf{4 5}$ & 8 \\
LMWF & 0.07 & 0.27 & $\mathbf{1 4}$ \\
\hline
\end{tabular}

States and southern terminus in Central America south of the Nicaraguan Depression;

D. Northern terminus of the range in Mexico north of the Isthmus of Tehuantepec and southern terminus in South America;

E Northern terminus of the range in Mexico north of the Isthmus of Tehuantepec and southern terminus in Central America south of the Nicaraguan Depression;

F. Northern terminus of the range in Mexico north of the Isthmus of Tehuantepec and southern terminus in Nuclear Middle America;

G Northern terminus of the range in Nuclear Middle America and the southern terminus in South America;

H. Northern terminus of the range in Nuclear Middle America and southern terminus in Central America south of the Nicaraguan Depression;

I. Restricted to Nuclear Middle America (exclusive of Honduran endemics);

J. Endemic to Honduras.

The data on broad distribution patterns in

Table 1 indicate that the largest number of species (19 or $26.0 \%$ of a combined total of 73 species) belong to category J, species endemic to Honduras. Thus, $23.8 \%$ of all the Honduran endemic species (80; J. R. McCranie unpubl. data) is found in Pico Bonito National Park. The next largest category is $\mathrm{D}$, with 13 species (17.8\%) with broad distributions extending from
Mexico north of the Isthmus of Tehuantepec into South America. Together, these two categories compose $43.8 \%$ of the combined total. The other seven categories contain from one to ten species and constitute, as a group, $56.2 \%$ of the total number.

\section{Ecological Distribution}

Of the 73 species of amphibians and reptiles in the park, 44 (60.3\%) come from Lowland Moist Forest, 45 (61.6\%) from Premontane Wet Forest, and 14 (19.2\%) from Lower Montane Wet Forest. In addition, 22 species (30.1\%) occur only in Lowland Moist Forest, 17 (23.3\%) only in Premontane Wet Forest, and five (6.8\%) only in Lower Montane Wet Forest.

Twenty-eight species (38.4\%) are arboreal, 41 (56.2\%) terrestrial, and four (5.5\%) arboreal and terrestrial (Table 1). With reference to occurrence in the three major habitats in the park (forest proper, streamside, pondside), 40 (54.8\%) were found only within the forest, 22 (30.1\%) only along streams, one $(1.4 \%)$ only around ponds; eight $(11.0 \%)$ occur in the forest and along streams, and two (2.7\%) in the forest and around ponds (Table 1).

In the forest, 23 (31.5\%) species are terrestrial, whereas 17 (23.3\%) are arboreal. Among streamside species, 12 (16.4\%) are terrestrial and six (8.2\%) are arboreal. There are four (5.5\%) arboreal-terrestrial streamside inhabitants, four (5.5\%) arboreal forest-streamside inhabitants, 
four $(5.5 \%)$ terrestrial forest-streamside inhabitants, two (2.7\%) terrestrial forest-pondside inhabitants, and one (1.4\%) arboreal pondside inhabitant.

\section{Relative Abundance}

The 73 species are classified as being common (many individuals regularly found), infrequent (unpredictable, few individuals seen), and rare (rarely seen). These classifications are historical (i.e., based largely on earlier trips) and do not take into consideration the population declines of some species (discussed below). Twenty-four species (32.9\%) are categorized as being common (two salamanders, 11 anurans, nine lizards, two snakes), 23 (31.5\%) as being infrequent (one salamander, five anurans, seven lizards, 10 snakes), and 26 (35.6\%) as being rare (three salamanders, four anurans, four lizards, 15 snakes).

\section{Population Declines}

Amphibian population declines are occurring in this national park, as elsewhere in Honduras (McCranie and Wilson 2002, Wilson and McCranie 2004a, McCranie 2005). Of the 26 species amphibian species recorded from the park, three appear to be extinct (Atelophryniscus chrysophorus, Eleutherodactylus chrysozetetes, and E. cruzi) and one extirpated (E. fecundus); each species is endemic to Honduras. McCranie and Wilson (2002) noted that tadpoles of Atelophryniscus chrysophorus were abundant in the Quebrada de Oro during each month the area was visited (see Material and Methods) on the first seven trips, although they were considerably less common on the 1996 trip than previously. No tadpoles or adults of A. chrysophorus were seen on the 2003 trip despite a diligent search of the Quebrada de Oro between 900-1100 $\mathrm{m}$ (the stream is non-flowing for much of the year above that point). Given the abundance of A. chrysophorus tadpoles along this stretch of Quebrada de Oro in previous years (it is easy to envision the previously abundant black tadpoles with prominent gold spots as the origin of the name of this stream), this is strong evidence of the collapse of this species. Eleutherodactylus chrysozetetes and E. fecundus were common along the Quebrada de Oro as late as the 1989 trip. Neither species was seen on the 1995, 1996, and 2003 trips despite working the same sections of the stream both day and night. Eleutherodactylus cruzi was last collected in 1980 at 1520 m elevation despite efforts to find it again in the region of its type locality in 1995 and 1996. Given the apparent disappearance of all streamside Eleutherodactylus in the country from similar elevations also strongly suggests this species is extinct.

Another four species (Duellmanohyla salvavida, Plectrohyla chrysopleura, Eleutherodactylus chac, and E. saltuarius) seem to have declining populations in the park. Three of these are endemic to Honduras and the other (E. chac) is otherwise restricted to Nuclear Middle America. All four of these species were decidedly less common in 1996 and 2003 than in earlier years and tadpoles of the Plectrohyla collected in 1996 had deformed mouthparts.

Parque Nacional Pico Bonito is home to five other Honduran amphibian endemics, Bolitoglossa porrasorum, Nototriton barbouri, Oedipina gephyra, Bufo leucomyos, and Ptychohyla spinipollex. Although we have insufficient data to comment on the status of the Oedipina, the other four species seem to have stable populations in the park.

Of the 47 species of reptiles from the park, three $(6.4 \%)$ seem to have declining populations. These are Drymobius chloroticus, Hydromorphus concolor, and Bothriechis marchi. The Bothriechis is endemic to Honduras. Two (D. chloroticus and B. marchi) are frog-eating snakes that formerly depended on the abundant anuran populations along the Quebrada de Oro. Parque Nacional Pico Bonito harbors five other Honduran reptile endemics, Sphaerodactylus dunni, Norops loveridgei, N. purpurgularis, N. zeus, and 
Typhlops stadelmani, each of which seems to have a stable population in the park.

Given the above-indicated documented cases of decline or disappearance, it is obviously critical that the populations of the species mentioned in this section be carefully monitored for changes in their population status.

\section{Discussion}

The herpetofauna of the mainland of Honduras, Bay Islands, Cayos Cochinos, Miskito Keys, and territorial waters comprises 348 species (J. R. McCranie unpubl. data), including 121 amphibian and 227 reptile species (six of which are marine in distribution). The herpetofauna of Parque Nacional Pico Bonito (73 species), therefore, represents $21.3 \%$ of the 342 mainland and insular species. The percentage of the various mainland and insular species afforded nominal protection in the park varies widely. None of the two species of caecilians, the nine species of non-marine turtles, nor the two crocodilians are known from the park. The percentages for the other groups are as follows: salamanders (23.1\% of 26 species); anurans (21.5\% of 93 species); lizards (22.5\% of 89 species); and snakes (22.3\% of 121 non-marine species).

However, the above figures are misleading, because Parque Nacional Pico Bonito contains only three (with the exclusion of the herpetologically unknown Premontane Moist Forest) of the nine forest formations found in Honduras. It is more useful to assess the park's importance by comparing the herpetofaunal composition by forest formation type with that of the same formation in the country as a whole. The forest formations found within the park for which the herpetofauna is sufficiently known are Lowland Moist Forest, Premontane Wet Forest, and Lower Montane Wet Forest. There are 64 amphibian species known from Lowland Moist Forest (McCranie and Wilson 2002, McCranie et al. 2002, 2003), 69 amphibian species from Premon- tane Wet Forest (J. R. McCranie unpubl. data), and 44 amphibian species from Lower Montane Wet Forest (Wilson and McCranie 2004b, c, McCranie et al. 2005). Thus, the 14 amphibian species found in Lowland Moist Forest in the park comprise $21.9 \%$ of the total known for that formation in Honduras, the 16 from Premontane Wet Forest make up 23.2\%, and the eight from Lower Montane Wet Forest constitute 18.2\%. The number of reptile species for these three formations are 141, 99, and 56, respectively (J. R. McCranie unpubl. data). Thus, the 30 reptile species from Lowland Moist Forest in the park make up $21.3 \%$ of the total recorded from that formation in Honduras, the 29 from Premontane Wet Forest constitute 29.3\%, and the six found in Lower Montane Wet Forest comprise 10.7\%.

As is the case with almost every other biotic reserve in Honduras (Wilson et al. 2001, McCranie and Wilson 2002, Wilson and McCranie 2003, 2004a, b, c, McCranie 2005), Parque Nacional Pico Bonito is impacted by anthropogenic environmental problems. Principal among them is habitat degradation and destruction brought about by slash-and-burn agriculture. This process is occurring apace throughout the buffer zone, as well as in the nuclear zone in the vicinity of the tributaries of the Río Cangrejal that emerge from the mountain range, including the Quebrada de Oro. Removal of the forest to make way for temporary croplands also set the stage for massive landslides that have disastrously altered the Quebrada de Oro and its environs from about 800-940 m elevation. These changes are directly implicated in the population declines seen in most anurans that reproduced in that section of the stream (Atelophryniscus chrysophorus, Duellmanohyla salvavida, and Plectrohyla chrysopleura). Only populations of Ptychohyla spinipollex seem not to have been negatively affected by this landslide-related alteration.

As noted above, almost one-fourth of the Honduran endemic species of amphibians and reptiles are recorded from Parque Nacional Pico Bonito (19 of a total of 80 or $23.8 \%$ ) in the central 
portion of the Cordillera Nombre de Dios. The high level of endemism of amphibians and reptiles in this reserve is part of a general pattern seen in the Cordillera Nombre de Dios. Refugio de Vida Silvestre Texíguat, located in the western portion of this cordillera also contains 19 endemic species of amphibians and reptiles (J. R. McCranie unpubl. data). In addition, Lowland Moist Forest in Honduras harbors a total of 14 endemic species of plants, all of which are found in the Cordillera Nombre de Dios (House 2001, House et al. 2002). These include Hepatanthus hazlettii, which represents not only an endemic species, but also an endemic genus and family of plants (House 2001, House et al. 2002). Concerning the amphibians, Atelophryniscus chrysophorus is not only an endemic species, but also belongs to an endemic and monotypic genus, confined to the moderate and intermediate elevations of the central and western portions of Cordillera Nombre de Dios (McCranie and Wilson 2002). Atelophryniscus is the only amphibian genus endemic to Honduras.

\section{Acknowledgements}

We thank G. A. Cruz, M. R. Espinal, S. W. Gotte, W. Holmes, J. Rindfleish, K. L. Williams, and L. D. Wilson for their help with the survey work. We also thank the personnel of the Departamento de Recursos Naturales and COHDEFOR, Tegucigalpa, for providing the permits that made the fieldwork possible. Our gratitude is also extended to V. Archaga, M. Moreno, and H. Portillo (PROBAP) for providing field equipment and logistic help. We also thank La Red de Análisis sobre Anfibios Neotropicales Amenazados (RANA) and National Science Foundation (DEB-0130273) for providing financial support for the field trip to the park in January and February, 2003. Our gratitude also goes to G. Rodriguez and all the personnel of $\mathrm{La}$ Fundación Parque Nacional Pico Bonito (FUPNAPIB) and El Centro Universitario Regional del Litoral Atlántico CURLA/UNAH for their support of our fieldwork.

\section{References}

Agudelo, N. 1987. Ecosistemas Terrestres de Honduras. Tegucigalpa. Asociación Hondureña de Ecología. $10 \mathrm{pp}$.

Anonymous. 2001. Estudio sobre Diversidad Biológica de la Republica de Honduras. Tegucigalpa. Multiprint. 159 pp.

Duellman, W. E. 1990. Herpetofaunas in neotropical rainforests: comparative composition, history, and resource use. Pp. 455-505 in A. H. Gentry (ed.), Four Neotropical Rainforests. New Haven, Connecticut. Yale University Press.

Espinal, M. R., J. R. McCranie and L. D. Wilson. 2001. The herpetofauna of Parque Nacional La Muralla, Honduras. Pp. 100-108 in J. D. Johnson, R. G. Webb and O. A. Flores-Villela (eds.), Mesoamerican Herpetology: systematics, zoogeography, and conservation. El Paso. Centennial Museum, University of Texas at El Paso, Special Publication.

Holdridge, L. R. 1967. Life Zone Ecology. Revised edition. San José, Costa Rica. Tropical Science Center. 206 pp.

House, P. 2001. Mapa de plantas endémicas de Honduras. In Memorias de la XIII Semana Científica. Tegucigalpa. Universidad Nacional Autónoma de Honduras.

House, P., C. Cerrato and D. Vreugdenhil. 2002. Rationalisation of the Protected Areas System of Honduras. Volume II: Biodiversity of Honduras. Tegucigalpa. Proyecto de Biodiversidad en Áreas Prioritarias PROBAP. 18 pp.

McCranie, J. R. 2005 (2004). The herpetofauna of Parque Nacional Cerro Azul, Honduras (Amphibia, Reptilia). Herpetological Bulletin 90: 10-21.

McCranie, J. R. and L. D. Wilson. 2002. The Amphibians of Honduras. Society for the Study of Amphibians and Reptiles, Contributions to Herpetology 19: i-x, 1-625.

McCranie, J. R., M. R. Espinal and L. D. Wilson. 2005. New species of montane salamander of the Bolitoglossa dunni group from northern Comayagua, Honduras (Urodela: Plethodontidae). Journal of Herpetology 39: 108-112.

McCranie, J. R., K. E. Nicholson and F. E. Castañeda. 2002. Geographic distribution. Eleutherodactylus diastema. Herpetological Review 33: 220.

McCranie, J. R., J. H. Townsend and L. D. Wilson. 2003. Hyla miliaria (Anura: Hylidae) in Honduras, with notes on calling site. Caribbean Journal of Science 39: 398-399.

Mejia, D. 1993. Informe del primer viaje al Parque Nacional Pico Bonito. Siguatepeque. Serie Misce- 
lanea de CONSEFORH Numero 44-26/93. 23 pp.

Sánchez, A., I. Oviedo, P. R. House, and D. Vreugdenhill. 2002. Racionalización del Sistema Nacional de Áreas Protegidas de Honduras. Volumen V. Estado legal de las áreas Protegidas de Honduras, actualización 2002. Tegucigalpa. Proyecto de Biodiversidad en Áreas Prioritarias PROBAP. 6 pP.

Thirakul, S. 1998. Manual de Dendrología para 146 Especies Forestales del Litoral Atlántico de Honduras. Segunda edición. Siguatepeque. Escuela Nacional de Ciencias Forestales. 502 pp.

Wilson, E. O. (ed.). 1988. Biodiversity. Washington. National Academy Press. xiii +521 pp.

Wilson, E. O. 1992. The Diversity of Life. Cambridge, Massachusetts. Belknap Press of Harvard University Press. 424 pp.

Wilson, E. O. and D. L. Perlman. 2000. Conserving Earth's Biodiversity with E. O. Wilson. Covelo. Island Press. (CD-ROM).

Wilson, L. D. and J. R. McCranie. 1998. Amphibian population decline in a Honduran national park. Froglog 25: 1-2.

Wilson, L. D. and J. R. McCranie. 2003. Herpetofaunal indicator species as measures of environmental stability in Honduras. Caribbean Journal of Science 39: 50-67.
Wilson, L. D. and J. R. McCranie. 2004a. The conservation status of the herpetofauna of Honduras. Amphibian and Reptile Conservation 3: 6-33.

Wilson, L. D. and J. R. McCranie. 2004b. The herpetofauna of the cloud forests of Honduras. Amphibian and Reptile Conservation 3: 34-48.

Wilson, L. D. and J. R. McCranie. 2004c. The herpetofauna of Parque Nacional El Cusuco, Honduras (Reptilia, Amphibia). Herpetological Bulletin 87: 13-24.

Wilson, L. D. and J. R. Meyer. 1985. The Snakes of Honduras. 2nd edition. Milwaukee. Milwaukee Public Museum. x +150 pp.

Wilson, L. D., J. R. McCranie and M. R. Espinal. 2001. The ecogeography of the Honduran herpetofauna and the design of biotic reserves. Pp. 109-158 in J. D. Johnson, R. G. Webb and O. A. Flores-Villela (eds.), Mesoamerican Herpetology: systematics, zoogeography, and conservation. El Paso. Centennial Museum, University of Texas at El Paso, Special Publication.

Young, B. E., G. Sedaghatkish, E. Roca and Q. D. Fuenmayor. 1999. El Estatus de la Conservación de la Herpetofauna de Panamá. Resumen del primer taller international sobre la herpetofauna de Panamá. The Nature Conservancy y Asociación Nacional para la Conservación de la Naturaleza (Ancon). 40 pp.

\section{Appendix I - Specimen Locality Data}

Bolitoglossa mexicana - Quebrada La Muralla, 160 m; Quebrada de Oro, 600 m.

Bolitoglossa porrasorum - S slope of Cerro Búfalo, 1520-1680 m; ridge N of Quebrada de Oro, $980 \mathrm{~m}$.

Bolitoglossa rufescens - CURLA Forestry Station, 120-160 m, USNM 559749; Quebrada de Oro, 820-990 m.

Nototriton barbouri - S slope of Cerro Búfalo, 1540 m; ridge N of Quebrada de Oro, 980 m.

Oedipina cyclocauda - 7.4 km SE of La Ceiba, 260 m; CURLA Forestry Station, 120-500 m.

Oedipina gephyra - S slope of Cerro Búfalo, $1580 \mathrm{~m}$.

Atelophryniscus chrysophorus - S slope of Cerro Búfalo, 1760 m; Quebrada de Oro, 750-1100 m.

Bufo leucomyos - CURLA Forestry Station, 120 m, USNM 559736-37; Quebrada de Oro, 770-1000 m; Los Planes, $500 \mathrm{~m}$.

Bufo marinus - CURLA Forestry Station, 120 m; Quebrada de Oro, 600 m; Quebrada La Muralla, $160 \mathrm{~m}$; Los Planes, $500 \mathrm{~m}$.

Bufo valliceps - 7.4 km SE of La Ceiba, 80-130 m; CURLA Forestry Station, 120 m; Quebrada La Muralla, 160 m; Quebrada de Oro, 600 m.

Hyalinobatrachium flesischmanni - Quebrada de Oro, $1000 \mathrm{~m}$ (specimen escaped).

Duellmanohyla salvavida - 7.4 km SE of La Ceiba, 90-290 m; Quebrada de Oro, 880-1000 m; N slope of Parque Nacional Pico Bonito. 
Plectrohyla chrysopleura - S slope of Cerro Búfalo, 1500-1550 m; Quebrada de Oro, 930-990 m.

Ptychohyla spinipollex - S slope of Cerro Búfalo, 1410-1580 m; mountains S of La Ceiba; Quebrada de Oro, 600-1100 m; Los Planes, $500 \mathrm{~m}$.

Smilisca baudinii - 7.4 km SE of La Ceiba, 80-290 m; $4.0 \mathrm{~km} \mathrm{~S} \mathrm{of} \mathrm{La} \mathrm{Ceiba;} \mathrm{CURLA} \mathrm{Forestry}$ Station, 100-130 m; Quebrada de Oro, $600 \mathrm{~m}$.

Eleutherodactylus aurilegulus - ca. $12 \mathrm{~km}$ ESE of La Ceiba, $100 \mathrm{~m}$; $7.4 \mathrm{~km}$ SE of La Ceiba, 80-120 m; CURLA Forestry Station, 120-130 m, USNM 559724; 7 km NW of Las Mangas, ca. 100 m; Quebrada La Muralla, 160 m; Quebrada de Oro, 600-1110 m, USNM 559725.

Eleutherodactylus chac - mountains N of CURLA Forestry Station, 730 m; Quebrada de Oro, 8001000 m, USNM 559727-28.

Eleutherodactylus chrysozetetes - Quebrada de Oro, 880-1130 m.

Eleutherodactylus cruzi - S slope of Cerro Búfalo, $1520 \mathrm{~m}$.

Eleutherodactylus fecundus - mountains S of La Ceiba; Quebrada de Oro, 780-1260 m.

Eleutherodactylus laticeps - S slope of Cerro Búfalo, $1270 \mathrm{~m}$.

Eleutherodactylus noblei - CURLA Forestry Station, 120-130 m.

Eleutherodactylus ridens - CURLA Forestry Station, 120-160 m; Quebrada de Oro, 880-960 m.

Eleutherodactylus saltuarius - S slope of Cerro Búfalo, 1550-1680 m.

Leptodactylus melanonotus - 7.4 km SE of La Ceiba, 80-290 m.

Rana maculata - Quebrada de Oro, 600-1100 m.

Sphaerodactylus dunni - 11.3 km SE of La Ceiba, ca. 100 m, LACM 437302-04; 7.4 km SE of La Ceiba, $230 \mathrm{~m}$ (uncatalogued).

Sphaerodactylus millepunctatus - $7.4 \mathrm{~km}$ SE of La Ceiba, $200 \mathrm{~m}$ (uncatalogued); CURLA Forestry Station, 120-130 m (uncatalogued).

Thecadactylus rapicauda - $7.4 \mathrm{~km}$ SE of La Ceiba, $200 \mathrm{~m}$ (uncatalogued); CURLA Forestry Station, $120 \mathrm{~m}$ (uncatalogued).

Basiliscus vittatus - CURLA Forestry Station, 120 m, USNM 508441; Quebrada de Oro, 860-1400 m, UTA R-41223-24, USNM 508437-40, 549377-79.

Corytophanes cristatus - Quebrada de Oro, 600-800 m, USNM 343746, 549401.

Sceloporus malachiticus - S slope of Cerro Búfalo, 1780 m, KU 194320; Quebrada de Oro, 830 m (uncatalogued).

Norops biporcatus - CURLA Forestry Station, $120 \mathrm{~m}$ (uncatalogued).

Norops lemurinus - 8 km SE of La Ceiba, ca. 80 m, KU 101392; CURLA Forestry Station, 120-200 m, SMF 77169-70, 77172-74, 78121-22, USNM 539841; Quebrada de Oro, 600-880 m, SMF 79220-21, USNM 539840; Los Planes, 560 m, UTA R-41940-41.

Norops loveridgei - S slope of Cerro Búfalo, 1510-1580 m, USNM 344802-04; Quebrada de Oro, 830-990 m, KU 219982, SMF 78793.

Norops purpurgularis - S slope of Cerro Búfalo, 1630-1820 m, USNM 344806-17, 508433-36.

Norops rodriguezii - S slope of Cerro Búfalo, 1500 m (uncatalogued); Quebrada de Oro, 780-990 m (uncatalogued).

Norops sericeus - 8 km SSE of La Ceiba, ca. 80 m, KU 101406.

Norops tropidonotus - 7.4 km SE of La Ceiba, ca. 100 m, SMF 79931-33; 8 km SE of La Ceiba, ca. 80 m, KU 101411-20; CURLA Forestry Station, 120 m, SMF 78039-40, 78704-11, 79056-58, 79943-46, 79948-50; Quebrada de Oro, 600-940 m, SMF 79244, 79930, USNM 539838-39.

Norops zeus - N slope of Cerro Búfalo, 650-900 m, SMF 80698, 80700; 7.4 km SE of La Ceiba, 200 m, USNM 541022; CURLA Forestry Station, 120-270 m, SMF 80699, 80701-02, USNM 541023-25; Liberia, 90 m, SMF 77193, 77196; Quebrada La Muralla, 350 m, SMF 77194-95. 
Eumeces sumichrasti - 7.4 km SE of La Ceiba, ca. $200 \mathrm{~m}$ (uncatalogued); CURLA Forestry Station, 120 m (uncatalogued); Quebrada de Oro, 880 m (sight record).

Sphenomorphus cherriei - $7.4 \mathrm{~km}$ SE of La Ceiba, $200 \mathrm{~m}$ (uncatalogued); CURLA Forestry Station, 120-480 m, USNM 508443; Quebrada de Oro, 810-1000 m, KU 200582, USNM 508442.

Ameiva festiva - ca. 12 km SSE of La Ceiba, 100 m, KU 101196-97; CURLA Forestry Station, 120 m (uncatalogued); Quebrada de Oro, 800-1000 m (uncatalogued).

Ameiva undulata - 8 km SE of La Ceiba, ca. 80 m, KU 101239-42; 12 km SSE of La Ceiba, 100 m, KU 101252-53; Quebrada de Oro, 800 m (uncatalogued); Los Planes, 560 m, UTA R-41266.

Cnemidophorus lemniscatus - ca. 12 km SSE of La Ceiba, 100 m, KU 101351; along Río Viejo, 400 m, KU 200584.

Lepidophyma flavimaculatum - CURLA Forestry Station, 120 m (uncatalogued); Quebrada de Oro, 940 m, USNM 508444.

Typhlops stadelmani - CURLA Forestry Station, 320 m, USNM 561070.

Boa constrictor - Quebrada de Oro, 780-940 m (photographs).

Ungaliophis continentalis - Quebrada de Oro, 990 m, USNM 344819.

Adelphicos quadrivirgatum - CURLA Forestry Station, 120 m, USNM 561020-21.

Chironius grandisquamis - CURLA Forestry Station, 120 m, USNM 508404; Quebrada de Oro, 780990 m, ROM 19964-65.

Clelia clelia - CURLA Forestry Station, 120 m, USNM 561110.

Coniophanes fissidens - Quebrada de Oro, 800-990 m, KU 200597, ROM 19966, USNM 508406.

Dendrophidion nuchale - Quebrada de Oro, 840 m, ROM 19970.

Dendrophidion percarinatum - CURLA Forestry Station, 120-500 m, USNM 559613-14.

Dryadophis melanolomus - CURLA Forestry Station, 120 m, USNM 559631; Quebrada de Oro, $840 \mathrm{~m}, \mathrm{ROM} 19972$.

Drymobius chloroticus - Quebrada de Oro, 780-940 m, KU 200601, 200605.

Drymobius margaritiferus - Quebrada de Oro, 800 m, ROM 19976.

Hydromorphus concolor - Quebrada de Oro, 900 m, FMNH 236400-01.

Imantodes cenchoa - S slope of Cerro Búfalo, 1620 m, USNM 343748; CURLA Forestry Station, 120 m, USNM 508413, 559647.

Lampropeltis triangulum - Quebrada de Oro, 1140 m, USNM 508415.

Leptodeira septentrionalis - Quebrada de Oro, 840-960 m, KU 200608, ROM 19982, USNM 343749.

Leptophis ahaetulla - ca. 12 km SSE of La Ceiba, 100 m, KU 101499; 7.4 km SE of La Ceiba, 130 m, ROM 19985; Quebrada de Oro, 870-1000 m, ROM 19983-84, USNM 559667.

Leptophis mexicanus - 5.6 km SSE of La Ceiba, ca. 60 m, LSUMZ 33723; Quebrada de Oro, 940 m, USNM 508421.

Ninia sebae - CURLA Forestry Station, 120 m, USNM 559679.

Oxybelis aeneus - CURLA Forestry Station, 120 m, USNM 559682.

Pseustes poecilonotus - 11.3 km SSE of La Ceiba, 100 m, LSUMZ 28399.

Sibon nebulatus - S slope of Cerro Búfalo, 1500 m, USNM 508424.

Xenodon rabdocephalus - CURLA Forestry Station, 130 m, USNM 559717.

Micrurus nigrocinctus - CURLA Forestry Station, 120 m, USNM 561081-83; Quebrada de Oro, 810830 m, KU 200630, ROM 20011; along Río Viejo, 400 m, KU 200631.

Bothriechis marchi - Quebrada de Oro, 1090 m, USNM 319942.

Bothriechis schlegelii - Quebrada de Oro, 860 m, USNM 319982.

Bothrops asper - Quebrada de Oro, 880-1160 m, KU 200507, ROM 20014. 


\section{Appendix II - Gazetteer}

Búfalo, Cerro - peak in Cordillera Nombre de Dios S of La Ceiba (also called Cerro Pelona by locals); collections made from 1000 to $1820 \mathrm{~m}\left(15^{\circ} 39^{\prime} \mathrm{N}, 86^{\circ} 48^{\prime} \mathrm{W}\right)$.

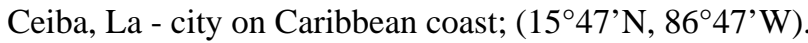

CURLA (Centro Universitario Regional del Litoral Atlántico) Forestry Station - forestry station that also allows visitors easy access to the national park, located ca. 11 airline km SW of La Ceiba; $120 \mathrm{~m}$ $\left(15^{\circ} 42^{\prime} \mathrm{N}, 86^{\circ} 51^{\prime} \mathrm{W}\right)$.

Liberia - small village in northern foothills of Cordillera Nombre de Dios, $3.5 \mathrm{~km} \mathrm{~S}$ of western end of La Ceiba airport; $90 \mathrm{~m}\left(15^{\circ} 42^{\prime} \mathrm{N}, 8^{\circ} 52^{\prime} \mathrm{W}\right)$.

Mangas, Las - village along Río Cangrejal $14 \mathrm{~km}$ SE of La Ceiba on road to Río Viejo; $140 \mathrm{~m}$ $\left(15^{\circ} 42^{\prime} \mathrm{N}, 86^{\circ} 43^{\prime} \mathrm{W}\right)$.

Muralla, Quebrada La - tributary of Río Cangrejal near Las Mangas; $160 \mathrm{~m}\left(15^{\circ} 42^{\prime} \mathrm{N}, 8^{\circ} 43^{\circ}\right.$ 'W).

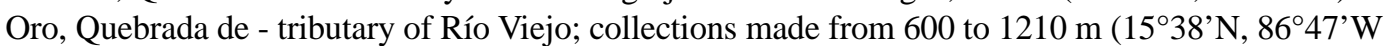
to $15^{\circ} 38^{\prime} \mathrm{N}, 86^{\circ} 48^{\prime} \mathrm{W}$ ).

Planes, Los - village near confluence of Quebrada de Oro with Río Viejo; 500 m (15³7’ N, 8646’W).

Viejo, Río - tributary of Río Cangrejal draining Cordillera Nombre de Dios in SE portion of Departamento de Atlántida. 